\title{
Under mountain Oltenia in the tourism globalization context
}

\author{
Cerasela Vintilescu \\ Technological High School Ştefan Anghel, 4 Revoluţiei Street, Băileşti, 205100, \\ Dolj, Romania \\ E-mail address: jonescus@yahoo.com
}

\begin{abstract}
The study starts from hypothesis that the tourism is an economic sector with endless resources, its globalization assuming valorizing and optimal use of these resources. It argues that in the context of the globalization of tourism, Sub-carpathian Oltenia offers great touristic potential varied as structure, consisting of natural and anthropogenic factors recognized scientifically, quantitatively and qualitatively and proven by practice. The region offers complex tourism resources whose valorization, amid technical and tourist facilities, in the context of protecting the quality of the geographical environment, can cause a tourism activity that would allow enrollment in the top of the tourist circuit. The globalization of tourism would contribute to economic growth of the area, to improve the living conditions and the attenuation of imbalances concerning development.
\end{abstract}

Keywords: tourism; economic growth; tourism globalization context

\section{INTRODUCTION}

Globalization is a complex process, that suppose the integration of a global phenomenon, and should not be viewed in terms of loss of individuality of communities, but from the universalisation of a set of values, of a uniform social space (by passing from socio-cultural autonomy of traditional groups, isolated, to generalization of interrelationships and communications) and to minimize the negative ecological, socio-cultural and economic impact of a region.Oltenia under the mountain is crossed on the direction west - east of DN 67 (MotruTârgu Jiu-Horezu- Râmnicu Vâlcea), an important access road artery that highlights the Oltenia Subcarpathian area of a remarkable landscape, being intersected by three European roads of high tourist traffic: E 81 - to Râmnicu Vâlcea, E 79 - to Târgu Jiu and E 70 to Drobeta Turnu Severin.

The tourism potential of the region is diversified represented by a picturesque landscape, and numerous monuments of art and architecture, some of them of international interest (referred to exemplify the work of Brâncuşi from Târgu Jiu), and a valuable folklore and ethnographic patrimony. Endowed with a great tourism potential, in which are enclosed diverse and spectacular carst forms, enjoying of a favorable clime for tourism, endowed with rich flora and fauna, with numerous natural and anthropogenic monuments, subcarpathian Oltenia could meet various segments of tourism demand. 


\section{TOURISM OPPORTUNITIES IN SUB-CARPATHIAN OLTENIA}

Sub-carphathians of Oltenia have two alignments of hills, at an average altitude between 300-600 m. Between the last mountain peaks and the first line of hills present a succession of small submountain depressions limited as area. So west of Bistriţa is Hurez Depression, bordered on the south by Măgura Slătioara $(767 \mathrm{~m})$, one of the most typical Subcarpathian hills of Oltenia. Ambience of this region have a special picturesque, resulting from the combination of the natural potential of the foothills (Bistriţa Keys Pietrenilor, massive limestone of Buila). The depression succession continues to west with Cerna Depression on the Cerna River, Racoviţa on the Tărâia River, Polovragi on the Olteţ River, Baia de Fier on Yellow Creek, Novaci on Gilort River, Stăneşti on Şuşiţa River, Bumbeşti Jiu on Jiu River, Runcu on Jaleş River, Celei on Tismana River and Pades on Motru River. The exception is the area of Bistrita Vâlcii and Olăneşti, where depressions are missing; there crossing from the mountains to hills is by saddles. The Olăneşti - Călimăneşti - Berislăveşti Corridor, typical contact corridor, appears as a succession of widening valley (Băile Olăneşti, Muereasca, Călimăneşti) connected by high saddles. After the second line of hills is deployed in west the widest depression range of our Subcarphatians: Târgu Jiu - Câmpu Mare Depression, a real water market.

Spelean domain is large and of the scientific and aesthetic value, many caves are protected by law and considered natural monuments and spelean areas. In Mehedintean carst, in Tismana village can be visited the Gura Plaiului Cave, interesting by regional endemism of Tismanella Chappuşi coleopteran, which is extraordinarily high number. In the south of the Căpătâni Mountains is Muierii Cave (18.75 hectares), containing a true cemetery of cave bear bones and important horizons Paleolithic cultures. On the left side of Oltet River, at the entrance to the gorge (known by their narrowness and wildness), is Polovragi Cave (on the territory of the same name village, on the DN 67 Route at the entrance to Gorj, from Valcea). Other numerous and impressive gorges replenish the carst patrimony of Oltenia Subcarpathian: Galben Keys, about $3 \mathrm{~km}$ from Baia de Fier, on the river with the same name, and Sohodol Keys (known as, "Gorj Canyon"), which develops about $10 \mathrm{~km}$, on the Sohodol River, being unique through tunnels dug by water in vertical walls, of colorful waterfalls, that fall from the slopes only during periods of rain.

In Valcea is characterized by uniqueness and scientific value, the Trovants Museum (, the growing stones") with two locations: Costeşti, on the left side of the road linking Râmnicu Vâlcea with Horezu, also near the Oteşani village, along the Gresarea Creek (about $16 \mathrm{~km}$ from Horezu, following the road to Craiova).

Climate, part of the geographical landscape, determines and influences tourism by favorable meteorological parameters of the tourism activities, it is a resource of climatic therapy (stimulating environment).

The waters are interested landscape, aesthetic, scientific in their hydroelectric potential. An important contribution has Olt Corridor, a true geographical axis plunges to the subcarpathian structures and converge the main lines of relief, and the major hydrographical system of the eastern part of the reference region. All floodplains between Topolog and Cerna, from the edge of the mountain, as certain arch on purpose to finish in Olt Corridor, and river valleys separating them, all roads carrying, facilitates links between the Olt Valley with the entire region and makes it to have favorable conditions to function as axis of polarization of the entire contents of this sector subcarpatic activities. In the west, Jiu River gathers the waters of several tributaries (Sadu, Tismana, Jiltu, Motru, Gilort, Amaradia etc.). In terms of tourism are noticed, also the salt lakes stands from Ocniţa and Ocnele Mari, but also artificial, arranged due to the construction of hydropower, which provides tourist interest by dams architecture 
and high gloss of the water: ex. Călimănesti (on the Olt River), Iovan Valley (on the Cerna River), Sâmbotin (on the Sadu River), Târgu Jiu (near Municipal Garden, central park of the town), Vâja (on the Bistrita River), and others.

Regarding hydrogeology in the Oltenian Subcarpathian is a wide variety of mineral fountain, which generated appeareance of some known spas. The oldest mineral waters are Săcelu, known and valued in the Dacian-Roman (proof the votive inscription on a monument, carved in stone by order of Marcus Tiberius Marcianus, thank god worshiped as the goddess of medicine Aesculapius and pharmacy Hygeia, which according to Alexandru Ştefulescu history, dates from the year $275 \mathrm{AD}$ ).

After I. Pişota (1983), the mineral fountains of the Oltenian Subcarpathian are classified as follows: sulfur (with hydrogen sulfide and sulfur), recognized as those of Călimăneşti Căciulata, Băile Olăneşti and Băile Govora; chlorine, with a high mineralization due the salt massifs, found at Ocnele Mari, Ocniţa etc. , oligominerals, with a low salt content, but also with curative in Râmnicu Vâlcea, Mateeşti şi Muereasca.

Vegetation and fauna required landscaping, aesthetic, recreational, bioclimatic, hunting, but interested in scientifically and by rare species (part of plant associations were declared reserves of flora: Chestnut Forest Pocruia - Tismana, on an area of 30,4 hectares, with chestnut species; Olteţ Keys on an over 20 hectares, sheltering about 400 species of plants, some of them unique to the country. Beauty of the subcarphatian landscape, with its components is reflected in the life of the inhabitants of these lands, in their habits and costumes, folklore and architecture.

Cultural elements are in a permanent relationship and interdependent with the tourism development of Subcarpathian Oltenia region. Regional specificities, integrated to the national one contributes to universalization, as one of the forms directly perceived of the globalization is the cultural one. Throughout the ancient world, the cultural tourism can build on the ruins of certain buildings / temples. Subcarpathian Oltenia can offer, in this regard, numerous monuments ruins dating from the same period of the most visited cultural sites of this kind in Greece and Minor Asia. In terms of ethnological, archaeological performed excavations in the Oltenian Subcarpathian revealed many traces of Dacian settlements, presumed to have developed on oldest seats and dating from the period of transition from the Neolithic to the Bronze Age (pre-Thracian civilization, whose main occupation grazing and crop production). They are generally funerary building that can attract many tourists, eager to complete their knowledge or simply admire them. An important economic center was the Buridava settlement (identified in the Ocnele Mari area), established for the operation and defense of the place of wealth priceless, salt. In Polovragi was identified, also a fortress and settlement dating from II $\mathrm{BC}$. The ruins of this type, however, were not preserved in their fair value, not giving due consideration to be valued in terms of tourism. Are required in this regard certain investments for infrastructure and their inclusion in the historical and cultural patrimony. Universalisation process of certain national values occurs when they respond to general human need and are transmitted from one nation to another through a mutual broadcast.

Moving time after, Dacian-Roman wars, appear new elements, needed to present GetoDacian peculiarities, with allochthonous cultural elements, and those of the Roman influence. From Daco-Roman period dates such as the hoards found at Dealu Mare, Sirineasa, Roman camp at Bumbeşti Jiu etc.

The cultural heritage of the Râmnicu Vâlcea and Târgu Jiu municipalities (where Brancusi monumental ensemble stands, where from "simple procedures, from the world of thoughts and feelings, the sculptor Constantin Brâncuşi made a work that perseveres and remains in the mind of man which contemplates, by simplicity and power of the feeling that 
the artist evokes all so simple and, at the same time elevating" (M. Nicolau-Golfin, 1972, p. 233 ) is supplemented by important monuments and religious assemblies scattered throughout the region: Tismana Monastery, Polovragi Monastery, Hurezi Monastery, Bistriţa Monastery, Govora Monastery, Frăsinei Monastery, Arnota Monastery, Cozia Monastery and many other historical and monastic art, treasures of historical and cultural heritage of Oltenia under the mountains.

Beyond craftsmen masons, talented and skilled, we find in the region, skilled carvers in wood and stone, and as meaningful traditions remember the clay processing. Millenary craft, pottery was and continues to be, in some rural areas a specialized activity, that only some villagers practice, among other occupations. It requires Hurezu famous pottery. The decor of ceramic is rich, performed with great finesse and special techniques. From the cultural point of view, Horezu stands and traditional Romanian handcrafts and textile handmade.

In the same note of the touristic interest we mention the variety of folklore costumes, maintained in a clear style units. Expression of cultural values in the subcarpathian area of Oltenia has to be reported to it. Folk Art includes traditional costume, but also the mastery to achieve it without a special technique, housing. If the architectural styles of the buildings and churches were changed to suit the founders, influenced by external currents, folk art remained unchanged. Go beyond the modest role that it occupies in the cultural tourism, it has followed her own development. Through it, as well as by his speech, Romanian peasant differs from its peers in neighboring regions and other nations.

\section{CONCLUSION}

Despite the complexity of interactions between societies, the increasing movement of images and extraordinary variety of promoting values, of ways of thinking and communication are unique features of the world space and of the new millennium. Few forms of globalization are so penetrating as the rise of popular culture and folklore manifestation of certain events that, despite the complexity of cultural interactions between societies, are unique features of the new millennium. We could say that we focus on an intercultural world in an unique space (world space) and at the same time (the synchronicity of the multicultural events).

\section{References}

[1] Cerasela Vintilescu (2011). Potenţialul turistic al judeţului Vâlcea. Craiova: Editura Legis.

[2] Aleksandra Vierek, International Letters of Natural Sciences 5 (2013) 59-70.

[3] L. Badea, D. Bugă (1992). Geografia României, IV, Regiunile pericarpatice. Bucureşti: Editura Academiei Române.

[4] Andrzej Borowski, International Letters of Social and Humanistic Sciences 11 (2014) $1-168$.

[5] Ştefan Vlăduţescu, European Scientific Journal 9 (2013).

[6] Dan Ionescu, Cristina Pretorian, International Letters of Social and Humanistic Sciences 9 (2014) 49-56. 
[7] Goran Rajović, Jelisavka Bulatović, International Letters of Natural Sciences 3 (2013) $1-6$.

[8] Ştefan Vlăduţescu; Ella Magdalena Ciupercă (2013). Next Flood Level of Communication: Social Networks. Aachen: Shaker Verlag.

[9] M. Nicolau-Golfin (1972). Istoria artei. vol. I, II. Bucureşti: Meridiane.

[10] Patricia Martínez García de Leaniz, Ignacio Rodríguez del Bosque, International Letters of Social and Humanistic Sciences 2 (2013) 51-55.

[11] M. Siminică, A. Traistaru, International Journal of Education and Research 1 (2013) 12.

[12] Alexandru Ştefulescu (1904). Gorjul istoric şi pitoresc. Târgu. Jiu: Tipografia N. D. Miloşescu.

[13] Mădălina Giorgiana Mangra; Elena Antoanela Cotoc; Aurelia Traistaru, Journal of Studies in Social Sciences 6(1) (2013) 1-14.

[14] I. Pişotă, I. Buta (1983). Hidrologie. Bucureşti: Editura Didactică şi Pedagocică.

[15] Ioan Constantin Dima; Ştefan Vlăduţescu (2012b). Persuasion elements used in logistical negotiation: Persuasive logistical negotiation. Saarbrucken: LAP Lambert Academic Publishing.

[16] Cerasela Vintilescu (2011). Potenţialul turistic al judeţului Gorj. Craiova: Editura Legis.

[17] Ştefan Vlăduţescu, American International Journal of Contemporary Research 3(10) (2013).

[18] Marin Drămnescu (2013). Postmodern Society and Individual Alienation. Revista de PSIHO terapie Experienţială.

[19] Enachescu, V. A., Journal of Community Positive Practices 13(2) (2013).

[20] L. Badea, P. Gâştescu, V. Velcea (Coord.) (1983). Geografia României. Geografie fizică. Bucureşti: Editura Academiei Române.

[21] Andrzej Borowski, International Letters of Social and Humanistic Sciences 3 (2013) 69-74.

[22] Ştefan Vlăduţescu, Journal of Studies in Social Sciences, 5(2) (2013) 276-287.

[23] Andrzej Borowski International Letters of Social and Humanistic Sciences 4 (2013) $70-74$.

[24] R. Bărbulescu, D. Ţâtu, L. Ţaţu (2007). Investment in human capital. EU integration opportunities, Romania within EU: opportunities, requirements and perspectives (pp. 430-435). V1. Sibiu: Editura Universităţii Lucian Blaga.

[25] Enachescu, V. A., Hristache, D. A.; Paicu, C. E., Review of Applied Socio-Economic Research 4(2) (2012) 93-96.

[26] F. Smarandache, Ş. Vlăduţescu (2013). Communication vs. Information, a Neutrosophic Solution. Neutrosophic Sets and Systems, 1.

[27] Janusz Grabara, Michal Kolcun, Sebastian Kot, International Journal of Education and Research 2(2) (2014) 1-8. 
[28] F. Smarandache, Ş. Vlăduţescu (2014). Neutrosophic Emergences and Incidences in Communication and Information. Saarbrucken: LAP Lambert Academic Publishing.

[29] Mihaela Gabriela Păun, International Letters of Social and Humanistic Sciences 6 (2014) 42-48.

[30] Bianca Teodorescu, International Letters of Social and Humanistic Sciences 12 (2014) 73-78.

[31] Andrzej Borowski, International Letters of Social and Humanistic Sciences 2 (2014) 110-121.

[32] Ştefan Vlăduţescu, International Letters of Social and Humanistic Sciences 10(2) (2014) 100-106.

[33] I. Stavre (2012). Internet and digital technology - influences on audiovisual communication and on teaching at master's degree level, Valencia, 2012, Published by International Association of Technology, Education and Development -ISBN: 978-84-615-5563-5

[34] Dan Ionescu, International Letters of Social and Humanistic Sciences 12 (2014) 57-65.

[35] Andrzej Borowski, International Letters of Social and Humanistic Sciences 6 (2013) 86-90.

[36] Aurelia Traistaru, Jokull 63(9) (2013) 125-135.

[37] Tomáš Hes, Anna Poledňáková, International Letters of Social and Humanistic Sciences 2 (2013) 18-31.

[38] Ştefan Vlăduţescu, Journal of Studies in Social Sciences 7(1) (2014) 19-31.

[39] Goran Rajović, Jelisavka Bulatović, International Letters of Natural Sciences 1 (2014) 33-53.

[40] E. A. Cotoc, A. Traistaru, A. Stoica, European Journal of Humanities and Social Sciences 25(1) (2013) 1316-1325. 